\title{
Synthesis of novel benzofurocoumarin analogues and their anti- proliferative effect on human cancer cell lines
}

\author{
C. S. Francisco, ${ }^{a}$ L. R. Rodrigues, ${ }^{b}$ N. M. F. S. A. Cerqueira, ${ }^{c}$ A. M. F. Oliveira- \\ Campos, ${ }^{\mathrm{a}}$ and L. M. Rodrigues ${ }^{\mathrm{a}}$ \\ ${ }^{a}$ Chemistry Centre, School of Sciences, University of Minho, Campus de Gualtar, 4710-057 Braga, \\ Portugal \\ ${ }^{\mathrm{b}}$ IBB - Institute for Biotechnology and Bioengineering, Centre of Biological Engineering, University of \\ Minho, Campus de Gualtar, 4710-057 Braga, Portugal \\ ${ }^{c}$ REQUIMTE, Faculdade de Ciências, Universidade do Porto, Rua do Campo Alegre s/n 4169-007 \\ Porto, Portugal.
}

\begin{abstract}
The synthesis of five new tetracyclic benzofurocoumarin (benzopsoralen) analogues is described. Their inhibitory effects on the growth of three human tumour cell lines (MDA MB 231 (breast adenocarcinoma), HeLa (cervix adenocarcinoma) and TCC-SUP (bladder transitional cell carcinoma)) were evaluated, and discussed in terms of structure-activity relationship.
\end{abstract}

\section{Keywords}

Benzofurocoumarins; Benzopsoralen analogues; Antitumour activity; Docking; Computational studies.

\section{Introduction}

Psoralens are natural products (linear furocoumarins) present in several plant families that are extremely toxic to a wide variety of prokaryotic and eukaryotic organisms. They may react directly with pyrimidine nucleotides forming mono- and di-adducts in DNA or even DNA interstrand cross-links [1,2]. Another cause of their toxicity derives from the ability of UV-A-photoactivated furocoumarins to react with ground state oxygen generating toxic oxyradicals capable of inactivating proteins within cells [3]. This type of reactivity has suggested their use as pharmaceuticals for a broad range of therapeutic applications requiring cell division inhibitors, such as vitiligo, psoriasis, and several types of cancer [4]. In this context, one of the main drug targets is the cytochrome P450 superfamily (CYPs), a large and diverse group of enzymes that catalyze the oxidation of organic substances, such as lipids, steroidal hormones, as well as xenobiotic 
substances. The inactivation mechanism of P450 by psoralens is not completely understood but is thought to occur in three different ways: a) binding of the inhibitor to the apoprotein, b) binding of the inhibitor to the heme, and c) reaction of the inhibitor with the heme inducing fragmentation. Once these processes have been triggered programmed cell death can occur unless repaired by cellular mechanisms $[2,5]$.

In humans, it is known that psoralens can behave as a general competitor substrate or act as a suicide inhibitor reacting with the heme group of the $\mathrm{P} 450$ proteins and therefore inactivating them. For instance, the 8-methoxypsoralen (xanthotoxin), 5methoxypsoralen (Bergapten) and psoralen have been reported to act as suicide inactivators of human-CYS2A6 protein in liver microsomes [6]. In addition, bergapten is a suicide inhibitor of human CYP3A4, and xanthotoxin competitively inhibits a variety of drug metabolites catalyzed by CYP3A4 [7]. All the above mentioned compounds are currently used as pharmaceuticals in the treatment of psoriasis [8,9], vitiligo [10], and T cell lymphoma [11].

These evidences have encouraged several research groups to study the synthesis and biological properties of new psoralen derivatives, including benzopsoralens [12-15]. These compounds were found to be effective in inhibiting the in vitro growth of different human tumour cell lines $[16,17]$. The synthesis of compounds, containing an ester group in the position 3 of the pyranone ring such as ethyl 3-oxo- $3 \mathrm{H}$ benzofuro[3,2-f]-1- benzopyran-2-carboxylate has also been described [18]. The angular compounds ethyl 3-oxo-3H-benzofuro[3,2-f]-1-benzopyran-2-carboxylate and ethyl 2oxo-2H-benzofuro[2,3- $h]$-1-benzopyran-3-carboxylate showed the most promising results on tumour cell lines [19], being the former the most active. Thus, in the current work this compound was hydrolyzed to the corresponding acid and its amide analogues were prepared, as well as the derivative unsubstituted in position 3 of the pyrone ring, to evaluate the effect of the structure variation on their biological activity. These results were complemented with molecular docking studies with human-CYS2A6 enzymes to evaluate the analogues potential to interact with the heme group of the enzymes.

\section{Results and Discussion}

\subsection{Chemistry}

Compound 1 was prepared as reported before [18] from the corresponding 2hydroxydibenzo[b,d]furan-1-carbaldehyde 2 by condensation with diethyl malonate to 
build the pyranone ring. Basic hydrolysis of the ester $\mathbf{1}$ resulted in the corresponding acid 3 with 67\% yield, which gave the expected $\mathrm{OH}$ signal as a very broad singlet at 13 ppm and the disappearance of the ethyl group. The acid derivative 3 was coupled to the ethyl ester of leucine by DCC/HOBt method, resulting in the product 4 with $38 \%$ yield.

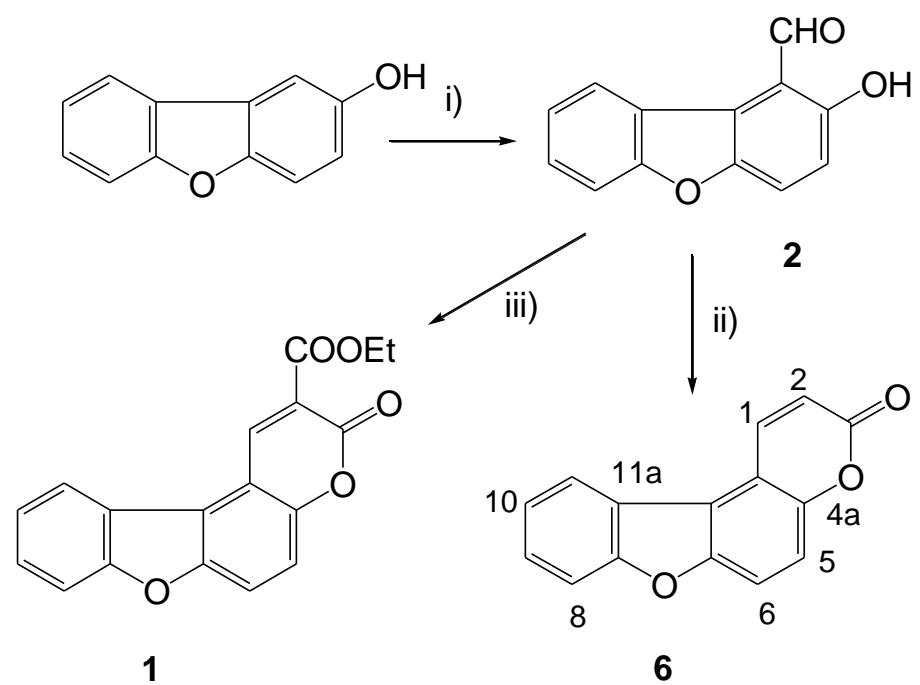

Scheme 1. Reaction conditions to obtain compounds 1, 2 and 6: i) $\mathrm{NaOH}, \mathrm{CHCl}_{3}, \mathrm{H}_{2} \mathrm{O}, 90^{\circ} \mathrm{C}$, 30 min. ii) phosphorane, $N, N$-diethylaniline, reflux, 22 hrs. iii) diethyl malonate, piperidine, acetic acid, ethanol, reflux, 6 hrs.

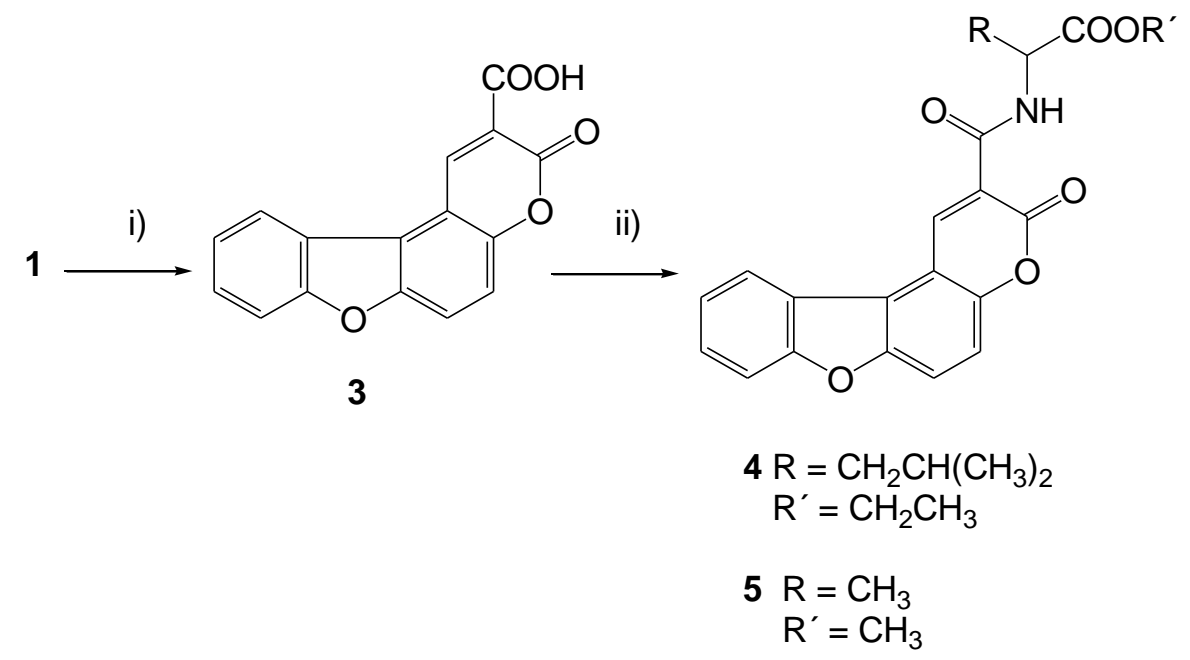

Scheme 2. Reaction conditions to obtain compounds 3,4 and 5: i) $\mathrm{NaOH}$, ethanol, $46^{\circ} \mathrm{C}, 4 \mathrm{hrs}$. ii) amino acid esters, HOBt, DCC, triethylamine, DMF, 48 - $72 \mathrm{hrs}$.

Unexpectedly, a low yield was obtained possibly due to the bulky amino acid side chain. The NMR data were in accordance with the expected for the final compound, namely the emergence of a doublet at $9.24 \mathrm{ppm}$ assigned to the amide $\mathrm{NH}$, the doublet at $1.02 \mathrm{ppm}$ due to the two $\mathrm{CH}_{3}$ groups of the amino acid side chain. 
The same coupling method was applied to the reaction of the acid $\mathbf{3}$ with the methyl ester of alanine resulting in the product 5 with $93 \%$ yield showing the expected signals in the NMR spectra.

The method described by Harayama and Ishii [20], in which the cinnamate was obtained by the Wittig reaction followed by ring closure, was used for the synthesis of compound 6. The yield obtained was low $(16 \%)$ mainly due to difficulties in the purification step. The ${ }^{1} \mathrm{H}$ NMR showed the typical signs, such as doublets at 8.50 and $6.65 \mathrm{ppm}$, with high coupling constant, corresponding to protons 1 and 2.

All the compounds were characterized by ${ }^{1} \mathrm{H}$ and ${ }^{13} \mathrm{C}$ NMR and elemental analysis or high resolution mass spectrometry.

\subsection{Anti-proliferative effect on human cancer cell lines}

The ability of the compounds to inhibit the in vitro growth of MDA MB 231, HeLa and TCC-SUP cell lines was evaluated and the results, given in concentrations that were able to cause $50 \%$ of cell growth inhibition (GI50), are summarized in Table 1.

A great anti-proliferative activity was observed for all the compounds even at the minimum concentration tested $(0.5 \mu \mathrm{M})$. Compound 1 was found to be the most effective against all cell lines. This compound was also found to be active against other tumour cell lines, namely MCF-7 (breast cancer), NCI-H460 (non-small cell lung cancer) and SF-268 (CNS cancer) [19].

Table 1. Anti-proliferative effect of the studied compounds on human cancer cell lines

\begin{tabular}{l|ccc}
\hline \multirow{2}{*}{ Compound } & \multicolumn{3}{|c}{ Inhibition of cancer cell lines GI50 $(\mu \mathrm{M})$} \\
\cline { 2 - 4 } & MDA MB 231 & HeLa & TCC-SUP \\
\hline $\mathbf{1}$ & $0.083 \pm 0.009$ & $0.002 \pm 0.000$ & $0.012 \pm 0.001$ \\
$\mathbf{3}$ & $0.097 \pm 0.011$ & $0.003 \pm 0.000$ & $0.050 \pm 0.011$ \\
$\mathbf{4}$ & $0.205 \pm 0.013$ & $0.043 \pm 0.008$ & $0.122 \pm 0.014$ \\
$\mathbf{5}$ & $0.106 \pm 0.008$ & $0.053 \pm 0.012$ & $0.159 \pm 0.023$ \\
$\mathbf{6}$ & $0.467 \pm 0.023$ & $0.005 \pm 0.001$ & $0.031 \pm 0.007$ \\
\hline
\end{tabular}

Compound 6 showed, within this set of experiments, the lowest activity for MDA MB 231; although for the other cell lines it gave values on the same range as compounds $\mathbf{1}$ and 3. 


\subsection{Molecular Docking}

Given that psoralens have been shown to be potent inhibitors of several enzymes from the cytochrome P450 superfamily, in the current work molecular docking methodologies were used to predict the binding pose between each of these ligands and the enzyme CYP2A6. The enzyme CYP2A6 was chosen since it is one of the 57 CYP isoenzymes found in humans [21] and it is involved in the metabolism of several pharmaceuticals, carcinogens, and a number of coumarin-type alkaloids [22, 23]. As previously mentioned, psoralens, such as xanthotoxin and Bergapten, have been shown to efficiently inhibit this enzyme, and contribute to the programmed cancer cell death and increased sensitivity to chemotherapy. Several studies demonstrated the antiproliferative effect of xanthotoxin and Bergapten on cancer cell lines, including B16F10 (melanoma cells), gastric adenocarcinoma (MK-1), breast cancer (MCF7 and T47D), and hepatocellular carcinoma [24-27]. The cytotoxic effect of these psoralens was also demonstrated against HeLa [25, 28-30] and MDA MB 231 [26, 31], which are the cell lines under study in the current work. Moreover, xanthotoxin was evaluated against the bladder carcinoma cell line EJ but the preliminary results were not very promising [32]. No data on TCC-SUP cells has been reported in the literature regarding the effect of xanthotoxin and Bergapten.
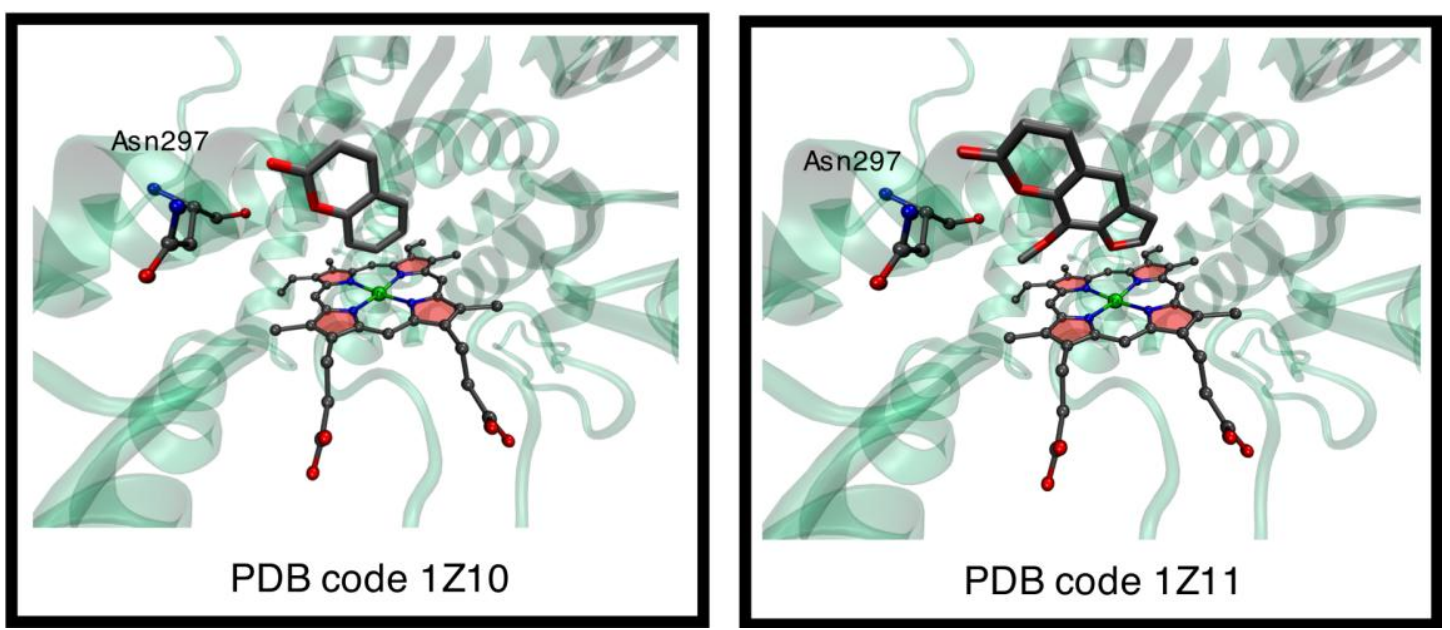

Figure 1. Close view of the active sites of CYP2A6 with the inhibitor (coumarin and xanthotoxin) bound in the active site (PDB codes $1 \mathrm{Z10}$ and 1Z11, respectively). The substrates are represented in bonds, the heme in ball and stick, and the protein in cartoon.

CYP2A6 uses a heme cofactor to oxidize the substrates. The active site of this enzyme is compact and composed by a hydrophobic Phe-cluster formed by residues Phe107, 
Phe111, Phe108, Phe209 and Phe480 (figure 1). In this region only one hydrogen bond donor is available and it is provided by Asn297, that directs the natural substrate (coumarin) towards regioselective oxidation [33].

Analyzing the X-ray structures available on the protein databank (www.pdb.org/pdb) for CYP2A6 complexed with the natural substrate (coumarin, PDB entry 1Z10) and with a linear psoralen inhibitor (xanthotoxin, PDB entry 1Z11), it was found that both compounds bind in a similar manner, and that the carbonyl group of the coumarin moiety interacts very closely with Asn297 [34]. The only observed difference was in the type of interactions nearby the iron atom from the heme cofactor. In the natural substrate, the position 7 of the coumarin ring is very close to this centre (3.09 $\AA$ ), thus favouring the hydroxylation reaction in this position. In the psoralen, it is the oxygen from the furan group that comes closer to this centre (3.25 $\mathrm{A})$. This result indicates that the inhibitory power of the psoralen may be related to the chelation of the oxygen from the furan ring with the iron from the heme, possibly resulting in the inactivation of the enzyme.

The molecular docking studies performed with compounds 1, 3-6 show that the binding poses of some of the compounds are very similar to those that are represented on figure 1 , while others differ significantly (figure 2).

The binding pose of compounds $\mathbf{1}$ and $\mathbf{6}$ are the closest ones, presenting the carbonyl group from the coumarin ring pointing towards the Asn297 (2.83 $\AA$ and $3.26 \AA$, respectively). However, these compounds interact with the ferryl heme of the CYP2A6 in different ways: compound $\mathbf{6}$ uses the position 10 (2.98 $\mathrm{A})$, while the compound $\mathbf{1}$ interacts directly through the oxygen from the furan ring, similarly to what was observed for the potent xanthotoxin inhibitor (illustrated on the right side of figure 1). 


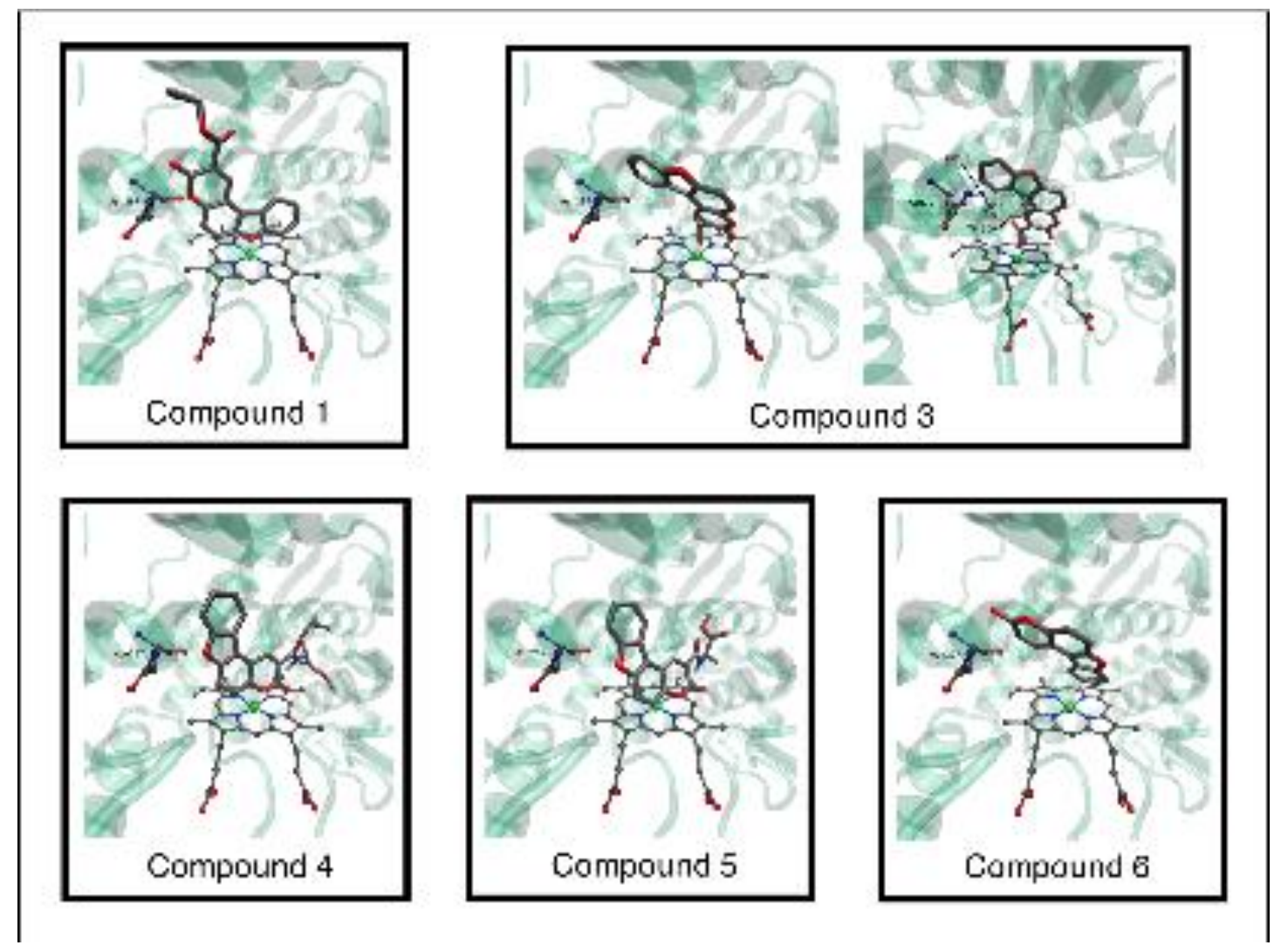

Figure 2. Psoralens 1, 3-6 docked in the active site of CYP2A6. The substrates are represented in bonds, the heme in ball and stick, and the protein in cartoon.

Compounds 4 and 5 were found to bind in the opposite direction of compounds 1 and $\mathbf{6}$. In those cases, the oxygen from the furan ring is located nearby the amino group of Asn297 (3.07 $\AA$ and $3.29 \AA$, respectively), while the oxygen from the coumarin moiety interact with the ferryl heme of the CYP2A6 (2.86 $\AA$ and $3.04 \AA$, and $3.07 \AA$ and 3.74 $\AA$, respectively). These results show that the active site region around Asn297 is quite narrow and cannot accommodate very large molecules. From all the studied psoralens with bulky groups at position 2, compound $\mathbf{1}$ is the only exception that was still able to bind similarly to the potent inhibitor xanthotoxin.

The binding pose of compound $\mathbf{3}$ is quite different from all the other studied compounds. The carboxylic group attached to carbon 2 of the psoralen was found to interact directly with the iron of the heme group (1.43 $\AA$ ) and to establish two hydrogen bonds with Gly301 and Thr275 (2.43 $\AA$ and $2.39 \AA$ ). The remaining part of the psoralen structure is pointing towards the Asn297, but is too far to interact with it (4.79 $\AA$ ), contrasting to what was observed for the other compounds.

Considering that most of the studied compounds interact predominantly with the Asn297 and with the iron from the heme cofactor of the CYP2A6, the electrostatic 
potential isosurfaces were calculated for all the synthesized compounds, in order to evaluate if there is any trend that might explain the observed docking poses (figure 3). The color-coded values of the isosurfaces provided an indication on the overall molecular size and the location of the positive and negative electrostatic potentials of the molecules (represented in yellow and orange in figure 3, respectively). These regions are determinant to differentiate the molecular recognition of the psoralens in the binding site of drug targets, as they provide important information about the regions that are more susceptible to a nucleophilic attack (positive regions), and those that present hydrogen-bond-accepting tendencies (negative regions).

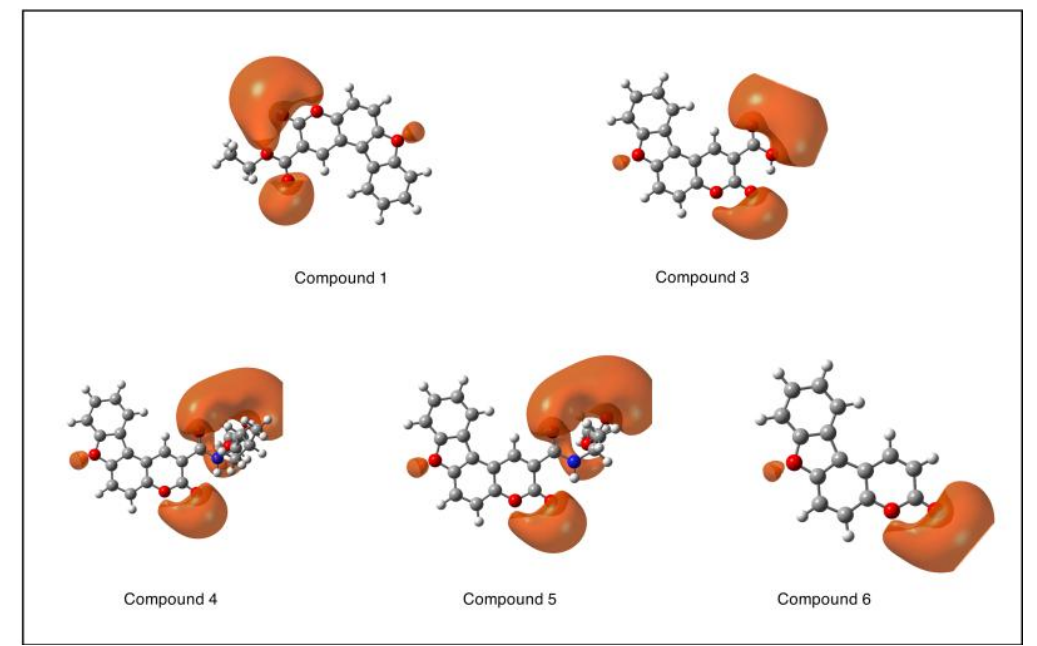

Figure 3. Electrostatic potential isosurfaces for the compounds 1, 3-6 (only the negative electrostatic potential is represented).

The results show that the negative electrostatic potential is located mainly over the oxygen atoms, while a null to positive potential is spread along the remaining parts of the psoralen structure. The negative electrostatic potential is mainly located in two areas, one over the furan oxygen, and the other across the oxygen atoms of the coumarin moiety. Taking into account the molecular docking studies, these regions are the ones that interact more closely with the binding site of CYP2A6, namely the Asn297 and the iron from the heme cofactor. Depending on the groups that are located on the position 2 of the coumarin ring, other bulky negative potential areas exist (compounds 1, 3, 4 and 5). Depending on the conformational arrangement of these groups, it might occur a superimposition on the negative electrostatic potential promoted by the coumarin ring. This effect improves the nucleophilic characteristics of the psoralens in those regions and renders them more reactive. This effect is observed in compounds $\mathbf{1}$ and $\mathbf{3}$, for which the two negatively electrostatic regions are superimposed, due to the vicinity of 
an oxygen atom from the ethoxycarbonyl and from the carboxyl group of the lactone. It is important to notice that these two compounds are those that show the best antiproliferative effect against most of the cell lines studied. Together with the molecular docking, these results suggest that this effect might favour the interaction of compound 1 with the Asn297 that is important for ligand recognition, or in the case of compound 3 to promote the direct chelation of the substrate with the heme group of the CYP2A6. The same effect is however not observed in compounds $\mathbf{4}$ and $\mathbf{5}$, in which the formation of intramolecular hydrogen bonds or even by the steric hindrance caused by the bulky groups precludes this effect. As a consequence, the most stable conformations for these compounds present these regions pointing towards the opposite direction of the other two common negative electrostatic potential regions that were previously described.

\section{Conclusions}

Five new benzofurocoumarins were synthesized and their biological activity tested. All of them significantly inhibited the proliferation of three human tumour cell lines, which we proposed to be mainly linked with the inhibition of CYP2A6.

The molecular docking results revealed that all of these compounds interact with the ferryl heme of CYP2A6 through an oxygen atom from their scaffold, with the exception of compound 6. This interaction is believed to be irreversible and block the activity of the active site for further reactions. We believe that this might be one of the main causes that preclude tumour cell proliferation.

From all the studied compounds, compounds $\mathbf{1}$ and $\mathbf{3}$ were found to be the most effective ones against all the studied cell lines with a GI50 of $2 \mathrm{nM}$ for the HeLa cell line. These compounds have identical scaffolds and only differ in the group that is attached to position 2 of the psoralen. Compound 3 has a carboxylic group in this position and it interacts very closely with iron through this group. In such case a strong chelation with the metal cannot be excluded. Compound $\mathbf{1}$ has an ester group in this position and it binds very similarly to what was observed for the potent xanthotoxin inhibitor that shows a close interaction between the oxygen of the furan ring with the iron from the heme $(2.83 \AA)$.

Compounds $\mathbf{4}$ and $\mathbf{5}$ can also interact with the iron of the heme with one oxygen atom, but due to the steric effect of the bulkier groups attached to position 2 of the psoralen, it is the oxygen from the lactone ring that interacts directly with this center. This 
interaction is however weaker when compared to those observed in compounds $\mathbf{1}$ and $\mathbf{3}$ due to the proximity of the ketone group that steals electron density from this atom. This effect is perhaps the main cause for the lower biological activity of these compounds against all cell lines. From these results we can conclude that due to the small size of the active site, the presence of bulkier groups at position 2 of the coumarin ring tend to decrease the biological activity of the compounds, due to the improper alignment of the psoralen in the active site.

Compound $\mathbf{6}$ is the only one that does not contain any group attached to the position 2 of the psoralen ring and does not have an oxygen atom pointing towards the iron. Even so, this compound shows good results in two cell lines: HeLa and TCC-SUP.

Comparing the binding pose of this compound with natural substrate (coumarin) present in the bound X-ray structure $1 Z 10$, we can conclude that they are very similar. This means that in such position compound $\mathbf{6}$ is in an optimal position to be hydroxylated at position 9 or 11 . We believe therefore that this compound can react in the active site and the product of this reaction might not inhibit only CYP2A6, but rather inhibit another enzyme and this might be the reason of the good results that are observed in some cell lines.

The results obtained in this study provide good indicators about the reactivity of the psoralenes in the CYP2A6. It has been shown that the interaction between the oxygen from the furan ring and the iron from the heme gives rises to the best biological activity. The residue Asn297 is important to orient and align the substrate in the active site but is not vital to induce enzyme inhibition. The presence of bulky substituents in the coumarin ring should be avoided since they tend to change the orientation of the psoralen in the active site which has a negative impact on their biological activity.

\section{Experimental}

\subsection{Chemistry}

\subsubsection{General}

Melting points were determined on a Gallenkamp melting point apparatus and are uncorrected. ${ }^{1} \mathrm{H}$ NMR (300 MHz) and ${ }^{13} \mathrm{C}$ NMR (75.4 MHz) spectra were recorded on a Varian Unity Plus Spectrometer at 298 K or on a Bruker Avance III 400 spectrometer (400 MHz for ${ }^{1} \mathrm{H}$ and $100.6 \mathrm{MHz}$ for ${ }^{13} \mathrm{C}$ ). Chemical shifts are reported in ppm relative 
to solvent peak or TMS; coupling constants $(J)$ are given in Hz. Double resonance, HMQC (heteronuclear multiple quantum coherence) and HMBC (heteronuclear multiple bond correlation) experiments were carried out for complete assignment of ${ }^{1} \mathrm{H}$ and ${ }^{13} \mathrm{C}$ signals in the NMR spectra. High-resolution mass spectra (ESI-TOF) were obtained on a Bruker FTMS APEXIII spectrometer. Elemental analyses were obtained on a Leco CHNS-932 instrument. TLC was carried out on plates coated with silica gel 60 F254. Column chromatography was performed on silica gel (70-230 or 230-400 mesh). Light petroleum refers to the fraction boiling in the range $40-60^{\circ} \mathrm{C}$.

\subsubsection{2-Hydroxydibenzo[b,d]furan-1-carbaldehyde (2)}

A solution of 2-hydroxydibenzofuran $(0.509 \mathrm{~g}, 2.76 \mathrm{mmol})$ in water $(50 \mathrm{~mL})$ and $\mathrm{NaOH}$ $(1.078 \mathrm{~g}, 0.027 \mathrm{mmol})$ was heated at $60{ }^{\circ} \mathrm{C}$ and $\mathrm{CHCl}_{3}(3 \times 0.22 \mathrm{~mL})$ was added, with stirring, over $30 \mathrm{~min}$. The mixture was heated at $90{ }^{\circ} \mathrm{C}$ for further $30 \mathrm{~min}$. After cooling, the reaction mixture was acidified with $10 \% \mathrm{HCl}$ and extracted with diethyl ether. The organic phase was dried $\left(\mathrm{MgSO}_{4}\right)$, and the solvent evaporated yielding a brown oil which was purified by column chromatography (diethyl ether/petroleum ether, 5:95). The compound 2 was obtained as a yellow solid. Yield: $0.113 \mathrm{~g}$ (0.53 mmol, $19 \%$ ). mp $125-126{ }^{\circ} \mathrm{C}$ (Lit. mp 135-138 ${ }^{\circ} \mathrm{C}$ [18]). ${ }^{1} \mathrm{H}-\mathrm{NMR}$ (DMSO- $d_{6}, 300$ MHz): $\delta 10.85$ (br s, 1H, OH), 10.70 (s, 1H, CHO), 8.85 (d, 1H, J = 8.1 Hz, H-9), 7.91 $(\mathrm{d}, 1 \mathrm{H}, J=9.0 \mathrm{~Hz}, \mathrm{H}-4), 7.68(\mathrm{~d}, 1 \mathrm{H}, J=8.4 \mathrm{~Hz}, \mathrm{H}-6), 7.56(\mathrm{dt}, 1 \mathrm{H}, J=1.2$ and $8.1 \mathrm{~Hz}$, H-7), 7.37 (dt, 1H, $J=1.2$ and $8.4 \mathrm{~Hz}, \mathrm{H}-8), 7.17$ (d, $1 \mathrm{H}, J=9.0 \mathrm{~Hz}, \mathrm{H}-3) .{ }^{13} \mathrm{C}-\mathrm{NMR}$ (DMSO- $d_{6}, 75.4$ MHz): $\delta 190.94$ (CHO), 159.21 (C-4a), 156.85 (C-5a), 149.22 (C-2), 128.64 (C-7), 126.02 (C-9), 123.04 (C-9a), 122.68 (C-8), 121.81 (C-9b), 119.77 (C-4), 116.86 (C-3 and C-1), 111.53 (C-6). Anal. Calcd. for $\mathrm{C}_{13} \mathrm{H}_{8} \mathrm{O}_{3}$ : C, 73.58, H, 3.80. Found: C, 73.05, H, 3.85.

\subsubsection{Ethyl 3-oxo-3H-benzofuro[3,2-f]chromene-2-carboxylate (1)}

The compound $2(0.105 \mathrm{~g}, 0.50 \mathrm{mmol})$ was dissolved in ethanol $(45 \mathrm{~mL})$ and a solution of diethyl malonate $(0.14 \mathrm{~mL}, 0.92 \mathrm{mmol})$ in ethanol $(5 \mathrm{~mL})$, piperidine $(0.2 \mathrm{~mL})$ and acetic acid $(0.2 \mathrm{~mL})$ were added and the mixture was refluxed for $6 \mathrm{~h}$. After cooling at room temperature it was left standing for $20 \mathrm{~h}$ at $5^{\circ} \mathrm{C}$, and compound 1 precipitated as a yellow solid. Yield: $0.083 \mathrm{~g}(0.27 \mathrm{mmol}, 54 \%)$. mp $153-154{ }^{\circ} \mathrm{C}$ (Lit. mp 167-169 ${ }^{\circ} \mathrm{C}$ [18]). ${ }^{1} \mathrm{H}-\mathrm{NMR}$ (DMSO- $d_{6}, 400 \mathrm{MHz}$ ): $\delta 9.13$ (s, 1H, H-1), 8.32 (d, $1 \mathrm{H}, J=7.6 \mathrm{~Hz}, \mathrm{H}-$ 
11), 8.07 (d, 1H, $J=9.2 \mathrm{~Hz}, \mathrm{H}-6$ ), 7.79 (d, 1H, $J=8.0 \mathrm{~Hz}, \mathrm{H}-8), 7.63$ (dt, 1H, $J=1.2$ and $7.2 \mathrm{~Hz}, \mathrm{H}-9), 7.58$ (d, 1H, $J=9.2 \mathrm{~Hz}, \mathrm{H}-5), 7.52$ (dt, $1 \mathrm{H}, J=0.8$ and $7.2 \mathrm{~Hz}, \mathrm{H}-10)$, 4.34 (q, 2H, $J=7.2 \mathrm{~Hz}, \mathrm{CH}_{2}$ ), 1.35 (t, 3H, $J=7.2 \mathrm{~Hz}, \mathrm{CH}_{3}$ ). ${ }^{13} \mathrm{C}-\mathrm{NMR}$ (DMSO-d 100.6 MHz): $\delta 162.77$ (CO-ester), 156.49 (C-7a), 155.88 (C-3), 151.49 (C-4a), 150.80 (C-6a), 143.22 (C-1), 128.81 (C-9), 123.92 (C-10), 122.65 (C-11), 122.17 (C-11a), 120.21 (C-11b), 118.82 (C-11c or C-2), 117.80 (C-6), 115.78 (C-5), 112.32 (C-8), $111.93(\mathrm{C}-2$ or $\mathrm{C}-11 \mathrm{c}), 61.53\left(\mathrm{CH}_{2}\right), 14.08\left(\mathrm{CH}_{3}\right)$. Anal. Calcd. for $\mathrm{C}_{18} \mathrm{H}_{12} \mathrm{O}_{5}: \mathrm{C}, 70.13$, H, 3.92. Found: C, 70.50, H, 3.72.

\subsubsection{3-Oxo-3H-benzofuro[3,2-f]chromene-2-carboxylic acid (3)}

The mixture of compound $1(0.083 \mathrm{~g}, 0.27 \mathrm{mmol})$ in ethanol $(20 \mathrm{~mL})$ and $1 \mathrm{M} \mathrm{NaOH}$ solution $(0.28 \mathrm{~mL})$ was stirred at $46^{\circ} \mathrm{C}$ for $3 \mathrm{~h}$. The ethanol was evaporated, water was added and the mixture acidified to $\mathrm{pH}=1$ with $1 \mathrm{M} \mathrm{HCl}$. A yellow solid separated which was identified as compound 3 (0.051 g, $0.18 \mathrm{mmol}, 67 \%)$. mp $258-261{ }^{\circ} \mathrm{C} .{ }^{1} \mathrm{H}-\mathrm{NMR}$ $\left(\mathrm{DMSO}-d_{6}, 400 \mathrm{MHz}\right): \delta 9.05$ (s, 1H, H-1), 8.24 (d, 1H, J = 8.0 Hz, H-11), 8.01 (d, $1 \mathrm{H}, J=9.2 \mathrm{~Hz}, \mathrm{H}-6), 7.74$ (d, 1H, $J=8.4 \mathrm{~Hz}, \mathrm{H}-8), 7.60$ (t, 1H, $J=7.6 \mathrm{~Hz}, \mathrm{H}-9), 7.51$ (d, $1 \mathrm{H}, J=9.2 \mathrm{~Hz}, \mathrm{H}-5), 7.47$ (t, $1 \mathrm{H}, J=7.6 \mathrm{~Hz}, \mathrm{H}-10)$. OH not observed. ${ }^{13} \mathrm{C}-\mathrm{NMR}$ (DMSO- $\left.d_{6}, 100.6 \mathrm{MHz}\right): \delta 164.05(\mathrm{COOH}), 156.45$ (C-7a or C-4a), 156.41 (C-7a or C4a), 151.43 (C-3 or C-6a), 151.42 (C-3 or C-6a), 142.90 (C-1), 128.75 (C-9), 123.96 (C10), 122.60 (C-11), 122.18 (C-11a), 120.12 (C-11b), 119.33 (C-2), 117.60 (C-6), 115.73 (C-5), 112.29 (C-8), 112.06 (C-11c). HRMS (ESI-TOF): Calcd. for $\mathrm{C}_{16} \mathrm{H}_{8} \mathrm{O}_{5}$ 280.037, found 280.0383. Anal. Calcd. for $\mathrm{C}_{16} \mathrm{H}_{8} \mathrm{O}_{5} .1 / 4 \mathrm{H}_{2} \mathrm{O}$ : C, 67.43; H, 2.98. Found: C, 67.49; $\mathrm{H}, 3.01$.

\subsubsection{Ethyl 4-methyl-2-(3-oxo-3H-benzofuro[3,2-f]chromene-2-carboxamido)} pentanoate (4)

To a solution of compound $\mathbf{3}(0.044 \mathrm{~g}, 0.157 \mathrm{mmol})$ in DMF (2 $\mathrm{mL})$ hydroxybenzotriazole $(0.0276 \mathrm{~g}, 0.16 \mathrm{mmol})$ was added. The mixture was cooled to 0 ${ }^{\circ} \mathrm{C}$ and $N, N^{\prime}$-dicyclohexylcarbodiimide $(0.0351 \mathrm{~g}, 0.166 \mathrm{mmol})$, triethylamine $(0.022$ $\mathrm{mL}, 0.157 \mathrm{mmol})$ and leucine ethyl ester hydrochloride $(0.031 \mathrm{~g} ; 0.157 \mathrm{mmol})$ were added. The mixture was stirred at room temperature for $48 \mathrm{~h}$. The urea derivative separated as a white solid which was filtered off and water $(10 \mathrm{~mL})$ was added to the filtrate. A yellow solid precipitated, and it was filtered affording compound $\mathbf{4}$. Yield: 
$0.025 \mathrm{~g}(0.060 \mathrm{mmol}, 38 \%)$. mp 153-155 ${ }^{\circ} \mathrm{C} .{ }^{1} \mathrm{H}-\mathrm{NMR}\left(\mathrm{CDCl}_{3}, 400 \mathrm{MHz}\right): \delta 9.62$ (s, $1 \mathrm{H}, \mathrm{H}-1), 9.25$ (d, 1H, J=7.2 Hz, NH), 8.30 (d, 1H, J = 7.2 Hz, H-11), 7.85 (d, 1H, $J=$ $8.8 \mathrm{~Hz}, \mathrm{H}-6), 7.67$ (d, 1H, $J=8.4 \mathrm{~Hz}, \mathrm{H}-8), 7.59$ (td, $1 \mathrm{H}, J=8.4$ and $1.2 \mathrm{~Hz}, \mathrm{H}-9), 7.49$ $(\mathrm{d}, 1 \mathrm{H}, J=9.0 \mathrm{~Hz}, \mathrm{H}-5), 7.46$ (td, $1 \mathrm{H}, J=8.4$ and $1.2 \mathrm{~Hz}, \mathrm{H}-10), 4.85-4.76(\mathrm{~m}, 1 \mathrm{H}, \alpha-$ $\mathrm{CH}), 4.26\left(\mathrm{q}, 2 \mathrm{H}, J=7.2 \mathrm{~Hz}, \mathrm{CH}_{2}\right), 1.83-1.77\left(\mathrm{~m}, 3 \mathrm{H}, \beta-\mathrm{CH}_{2}\right.$ and $\left.\gamma-\mathrm{CH}\right), 1.33(\mathrm{t}, 3 \mathrm{H}, J$ $\left.=7.2 \mathrm{~Hz}, \mathrm{CH}_{\underline{3}}\right), 1.02\left(\mathrm{~d}, \mathrm{~J}=6.9 \mathrm{~Hz}, 6 \mathrm{H}, 2 \times \mathrm{CH}_{3}\right) \cdot{ }^{13} \mathrm{C}-\mathrm{NMR}\left(\mathrm{CDCl}_{3}, 100.6 \mathrm{MHz}\right): \delta$ 172.27 (C-ester), 161.46 (C3 or C-amide), 161.06 (C-3 or C-amide), 157.33 (C-7a), 152.35 (C-6a), 151.47 (C-4a), 144.52 (C-1), 128.70 (C-9), 123.84 (C-10), 122.80 (C11a), 122.51 (C-11), 121.32 (C-11b), 118.06 (C-11c), 117.73 (C-6), 115.32 (C-5), 113.16 (C-2), 112.43 (C-8), $61.37\left(\mathrm{CH}_{2}\right.$ ester), 51.74 (C- $\left.\alpha\right), 41.15(\mathrm{C}-\beta), 25.05(\mathrm{C}-\gamma)$, 22.88 ( $\mathrm{CH}_{3}$-leucine), 21.87 ( $\mathrm{CH}_{3}$-leucine), 14.19 ( $\mathrm{CH}_{3}$ ester). HRMS (ESI-TOF) calcd for $\mathrm{C}_{24} \mathrm{H}_{23} \mathrm{NO}_{6} 422.15981[\mathrm{M}+\mathrm{H}]^{+}$, found 422.15971. Anal. Calcd. for $\mathrm{C}_{24} \mathrm{H}_{23} \mathrm{NO}_{6}: \mathrm{C}$, 68.40; H, 5.50; N, 3.32. Found: C, 68.45; H, 5.88; N, 3.34.

\subsubsection{Methyl 2-(3-oxo-3H-benzofuro[3,2-f]chromene-2-carboxamido)propanoate (5)}

To a solution of compound $\mathbf{3}(0.087 \mathrm{~g}, 0.311 \mathrm{mmol})$ in DMF (3 $\mathrm{mL})$ hydroxibenzotriazole $(0.048 \mathrm{~g}, 0.311 \mathrm{mmol})$ was added and the mixture cooled at $0{ }^{\circ} \mathrm{C}$. $N, N^{\prime}$ - dicyclohexylcarbodiimide $(0.077 \mathrm{~g}, 0.34 \mathrm{mmol})$, triethylamine $(0.044 \mathrm{~mL}, 0.311$ $\mathrm{mmol})$ and alanine methyl ester hydrochloride $(0.0435 \mathrm{~g} ; 0.311 \mathrm{mmol})$ were added, and the mixture was kept stirring at room temperature for $48 \mathrm{~h}$. The urea derivative separated as a white solid which was filtered off and water $(25 \mathrm{~mL})$ was added to the filtrate. A yellow solid precipitated and it was filtered affording compound 5. Yield: $0.1043 \mathrm{~g}(0.29 \mathrm{mmol}, 93 \%)$. mp 140-143 ${ }^{\circ} \mathrm{C} .{ }^{1} \mathrm{H}-\mathrm{NMR}\left(\mathrm{CDCl}_{3}, 300 \mathrm{MHz}\right): \delta 9.61$ (s, 1H, H-1), 9.35 (d, 1H, J = 6.9 Hz, NH), 8.29 (d, 1H, $J=8.1 \mathrm{~Hz}, \mathrm{H}-11), 7.86$ (d, 1H, $J$ $=9.0 \mathrm{~Hz}, \mathrm{H}-6), 7.67$ (d, 1H, $J=8.1 \mathrm{~Hz}, \mathrm{H}-8), 7.60$ (td, $1 \mathrm{H}, J=8.4$ and $1.2 \mathrm{~Hz}, \mathrm{H}-9)$, $7.50(\mathrm{~d}, 1 \mathrm{H}, J=9.0 \mathrm{~Hz}, \mathrm{H}-5), 7.48(\mathrm{td}, 1 \mathrm{H}, J=7.8$ and $0.9 \mathrm{~Hz}, \mathrm{H}-10), 4.80$ (qui, 1H, $J$ $=7.2 \mathrm{~Hz}, \alpha-\mathrm{CH}), 3.83\left(\mathrm{~s}, 3 \mathrm{H}, \mathrm{OCH}_{3}\right), 1.61\left(\mathrm{~s}, 3 \mathrm{H}, J=7.5 \mathrm{~Hz}, \beta-\mathrm{CH}_{3}\right) .{ }^{13} \mathrm{C}-\mathrm{NMR}$ $\left(\mathrm{CDCl}_{3}, 75.4 \mathrm{MHz}\right): \delta 172.77$ (C-ester), 161.26 (C-3 or C-amide), 161.00 (C-3 or Camide), 157.31 (C-7a), 152.34 (C-6a), 151.47 (C-4a), 144.54 (C-1), 128.72 (C-9), 123.86 (C-10), 122.77 (C-11a), 122.48 (C-11), 121.31 (C-11b), 117.93 (C-11c), 117.79 (C-6), 115.34 (C-5), 113.11 (C-2), 112.44 (C-8), 52.56 ( $\mathrm{CH}_{3}$ ester), $48.84(\mathrm{C}-\alpha), 17.95$ (C- $\beta$ ). HRMS (ESI-TOF) calcd for $\mathrm{C}_{20} \mathrm{H}_{15} \mathrm{NO}_{6} 366.09720[\mathrm{M}+\mathrm{H}]^{+}$, found 366.09720. 


\subsubsection{H-Benzofuro[3,2-f]chromen-3-one (6)}

To a solution of compound $2(0.147 \mathrm{~g}, 0.69 \mathrm{mmol})$ in $N, N$-diethylaniline $(4.1 \mathrm{~mL})$, carbetoxymethylene-triphenyl-phosphorane $(0.334 \mathrm{~g}, 0.97 \mathrm{mmol})$ was added. The mixture was refluxed for $22 \mathrm{~h}$. After cooling, water $(15 \mathrm{~mL})$ was added and the mixture was extracted with diethyl ether $(4 \mathrm{x} 10 \mathrm{~mL})$. The combined organic layers were washed with $10 \% \mathrm{HCl}$ solution $(3 \times 10 \mathrm{~mL})$, dried $\left(\mathrm{MgSO}_{4}\right)$, and the solvent was evaporated. The residue obtained was purified by column chromatography using petroleum ether/ diethyl ether (95:5) as eluent. The compound (6) was obtained as a yellow solid (0.025 g, $11 \mathrm{mmol}, 16 \%)$. mp 159-161 ${ }^{\circ} \mathrm{C} .{ }^{1} \mathrm{H}-\mathrm{NMR}\left(\mathrm{CDCl}_{3}, 400 \mathrm{MHz}\right): \delta 8.50(\mathrm{~d}, 1 \mathrm{H}, J=$ $9.6 \mathrm{~Hz}, \mathrm{H}-1), 8.11$ (ddd, 1H, $J=7.7,1.2$ and $0.8 \mathrm{~Hz}, \mathrm{H}-11), 7.74$ (d, 1H, $J=8.8 \mathrm{~Hz}, \mathrm{H}-$ 6), 7.67 (dt, $1 \mathrm{H}, J=8.4$ and $0.8 \mathrm{~Hz}, \mathrm{H}-8), 7.57$ (dt, $1 \mathrm{H}, J=7.6$ and $1.2 \mathrm{~Hz}, \mathrm{H}-9$ ), $7.48-$ 7.41 (m, 2H, H-10 and H-5), 6.65 (d, 1H, $J=9.6 \mathrm{~Hz}, \mathrm{H}-2) .{ }^{13} \mathrm{C}-\mathrm{NMR}\left(\mathrm{CDCl}_{3}, 100.6\right.$ MHz): $\delta 160.53$ (C-3), 157.12 (C-7a), 152.22 (C-6a), 150.82 (C-4a), 139.43 (C-1), 128.08 (C-9), 123.46 (C-10), 123.23 (C-11a), 121.84 (C-11), 119.91 (C-11b), 117.29 (C-2), 115.98 (C-5), 115.26 (C-6), 113.39 (C-11c), 112.47 (C-8). HRMS (ESI-TOF) calcd for $\mathrm{C}_{15} \mathrm{H}_{8} \mathrm{O}_{3} 236.0473[\mathrm{M}]^{+}$, found 236.0479. Anal. Calcd. for $\mathrm{C}_{15} \mathrm{H}_{8} \mathrm{O}_{3} \cdot 1 / 4 \mathrm{H}_{2} \mathrm{O}: \mathrm{C}$, 74.84; H, 3.56. Found: C, 75.14; H, 3.90.

\subsection{Tumour cell growth assay}

The compounds were evaluated for their anti-proliferative effect on human cancer cell lines MDA MB 231 (breast adenocarcinoma), HeLa (cervix adenocarcinoma) and TCCSUP (bladder transitional cell carcinoma). The MDA MB 231 epithelial cell line was established from a pleural effusion obtained from a 51-year-old female patient with breast cancer. The HeLa cell line was established from the epitheloid cervix carcinoma of a 31-year-old woman; later diagnosis changed to adenocarcinoma. The TCC-SUP cell line was established from a tumour specimen resected from the urinary bladder transitional cell carcinoma (undifferentiated, grade IV) of a 67-year-old woman. All the cell lines were kindly provided by IPATIMUP (Portugal). The cells were maintained in an incubator with a $5 \% \mathrm{CO}_{2}$ atmosphere and at $37^{\circ} \mathrm{C}$. The culture medium used was the Dulbecco’s modified Eagle medium (DMEM) (GIBCO ${ }^{\circledR}$, Invitrogen, Barcelona, Spain) supplemented with $10 \%$ of Fetal Bovine Serum (FBS) (GIBCO ${ }^{\circledR}$, Invitrogen, Barcelona, Spain) (except for TCC-SUP cell line for which 15\% FBS was used) and 1\% of penicillin/streptomycin (Invitrogen, Barcelona, Spain). 


\section{Cell Viability}

Cells were exposed to five concentrations of compounds starting from a maximum concentration of $75 \mu \mathrm{M}$. Compounds, prepared in dimethyl sulfoxide (DMSO), were freshly diluted with cell culture medium just prior the assays. Final concentrations of DMSO did not interfere with the cell lines growth. The cell viability was determined using the MTS (3-(4,5-dimethylthiazol-2-yl)-5-(3-carboxymethoxyphenyl)-2-(4sulfophenyl)-2H-tetrazolium) method. A commercial kit was used according to the manufacturer instructions (Promega, PROM G35800001, Lisbon, Portugal). In these experiments, $100 \mu \mathrm{L}$ of cell suspension was added to each well of a 96-well plate. Additionally, control wells were included consisting of DMEM medium and the compounds prepared in DMSO at the concentrations under study. When a cell concentration of $1 \times 10^{5}$ cells $/ \mathrm{mL}$ was obtained, adequate volumes of the compounds solutions were added to the wells and incubated for 48 hours. Afterwards, $20 \mu \mathrm{L}$ of the CellTitter 96 AQueous One Solution Cell Proliferation Assay reagent (MTS) was added to each well and left in the incubator $\left(37^{\circ} \mathrm{C}, 5 \% \mathrm{CO}_{2}\right)$ for 2 hours after which the cell viability was quantified by recording the absorbance at $490 \mathrm{~nm}$. For each test compound and for each cell line a dose-response curve was generated and the growth inhibition of $50 \%$ (GI50), corresponding to the concentration of compound that inhibits $50 \%$ of the cell growth was determined. The results are expressed as percentage of viable cells compared to the control and represent an average of 3 independent cultures with 4 wells per concentration in each experiment.

\subsection{Molecular Docking}

All psoralen-derived compounds were studied using the molecular docking software AutoDock [35] and the vsLab plug-in [36]. The structure of the receptor was built from the PDB structure 1 Z10 containing the Human Microsomal P450 2A6. The ligands were built with GaussView, protonated at physiological $\mathrm{pH}$ and optimized with gaussian09 $(\mathrm{HF} / 6-31 \mathrm{G}(\mathrm{d}))$. In the docking process the Lamarckian genetic algorithm (LGA) was used. The number of generations, energy evaluations, and docking runs were set to 370000, 1500000, and 50, respectively. The atomic charges were considered as Kollman-all-atom for the receptor and Gasteiger for the compounds. The final solutions were retrieved from the molecular docking process according to the criteria of 
interacting energy.

\subsection{Electrostatic potential:}

The three-dimensional electrostatic potential isosurfaces for each compound were obtained using the software gaussian09 [37] and generated using the CUBEGEN utility. All the geometries were previously optimized with the Hartree-Fock level of theory and with the $6-31+\mathrm{G}(\mathrm{d}, \mathrm{p})$ basis set. The molecular electrostatic potential (values ranging from $-56 \mathrm{kcal} / \mathrm{mol}$ to $56 \mathrm{kcal} / \mathrm{mol}$ ) was mapped onto $0.002 \mathrm{e} / \mathrm{bohr}^{3}$ electron density surfaces with GaussView.

\section{Acknowledgements}

We acknowledge the financial support from FCT and FEDER, for National NMR Network (Bruker Avance II 400), REEQ/630/QUI/2005 (LC/MS instrument) and the PhD grant (SFRH/BD/48636/2008).

\section{References}

[1] J.D. Laskin, E. Lee, E.J. Yurkow, D.L. Laskin, M.A. Gallo, A possible mechanism of psoralen phototoxicity not involving direct interaction with DNA, Proc. Natl. Acad. Sci. USA, 82 (1985) 6158-6162.

[2] R. Gambari, I. Lampronti, N. Bianchi, C. Zuccato, G. Viola, D. Vedaldi, F. Dall'Acqua, Structure and biological activity of furocoumarins, Top. Heterocycl. Chem., 9 (2007) 265-276.

[3] A.K. Gupta, T.F. Anderson, Psoralen photochemotherapy, J. Am. Acad. Dermatol., 17 (1987) 703-734.

[4] H.E. Kleiner, S.V. Vulimiri, M.J. Reed, A. Uberecken, J. DiGiovanni, Role of cytochrome P450 1a1 and 1b1 in the metabolic activation of 7,12-dimethylbenz[a]anthracene and the effects of naturally occurring furanocoumarins on skin tumor initiation, Chem. Res. Toxicol., 15 (2002) 226-235.

[5] L. Koenigs, W. Trager, Mechanism-based inactivation of P450 2A6 by furanocoumarins, Biochem., 37 (1998) 10047-10061.

[6] L. Koenigs, R. Peter, S. Thompson, A. Rettie, W. Trager, Mechanism-based inactivation of human liver cytochrome P450 2A6 by 8-methoxypsoralen, Drug. Metab. Dispos., 25 (1997) 1407-1415.

[7] P.C. Ho, D.J. Saville, S. Wanwimolruk, Inhibition of human CYP3A4 activity by grapefruit flavonoids, furanocoumarins and related compounds, J. Pharm. Pharm. Sci., 4 (2001) 217-227.

[8] I.M. Zonneveld, L. Witkamp, P.M.M. Bossuyt, M.M.H.M. Meinardi, J.D. Bos, The effectiveness of cyclosporine and photochemotherapy in the treatment of psoriasis: a retrospective study, J. Eur. Acad. Dermatol., 9 (1997) 232-236.

[9] E. Adisen, F. Karaca, M. Oztas, M.A. Gurer, Efficacy of local psoralen ultraviolet A treatments in psoriasis, vitiligo and eczema, Clin. Exp. Dermatol., 33 (2008) 344-345.

[10] P.E. Grimes, Psoralen photochemotherapy for vitiligo, Clin. Dermatol., 15 (1997) 921-926.

[11] H. Honigsmann, W. Brenner, W. Rauschmeier, K. Konrad, K. Wolff, Photochemotherapy for cutaneous T cell lymphoma. A follow-up study, J. Am. Acad. Dermatol., 10 (1984) 238-245. [12] A. Chilin, C. Marzano, A. Guiotto, P. Manzini, F. Baccichetti, F. Carlassare, F. Bordin, Synthesis and biological activity of (Hydroxymethyl)- and (diethylaminomethyl)benzopsoralens, J. Med. Chem., 42 (1999) 2936-2945. 
[13] S. Mobilio, L. Tondelli, M. Capobianco, O. Gia, Sequence Specificity of Tetrahydrobenzopsoralen Photobinding to DNA, Photochem. Photobiol., 61 (1995) 113-117.

[14] M. Palumbo, P. Rodighiero, O. Gia, A. Guiotto, S.M. Magno, Benzofurocoumarins - New Monofunctional DNA-Photobinding Agents, Photochem. Photobiol., 44 (1986) 1-4.

[15] O. Gia, S. Mobilio, M. Palumbo, M.A. Pathak, Benzo-Psoralen and TetrahydrobenzoPsoralen Congeners - DNA-Binding and Photobiological Properties, Photochem. Photobiol., 57 (1993) 497-503.

[16] V.C. Leite, R.F. Santos, L.C. Chen, L.A. Guillo, Psoralen derivatives and longwave ultraviolet irradiation are active in vitro against human melanoma cell line, J. Photoch. Photobio. B, 76 (2004) 49-53.

[17] A.M.A.G. Oliveira, A.M.F. Oliveira-Campos, L.M. Rodrigues, M.M.M. Raposo, A.E.H. Machado, M.S.J. Nascimento, N. Nazareth, M. Pinto, Synthesis and Antitumour Evaluation of Benzopsoralen Analogues, Chem. Biodivers, 4 (2007) 980-990.

[18] A.M.A.G. Oliveira, M.M.M. Raposo, A.M.F. Oliveira-Campos, J. Griffiths, A.E.H. Machado, Synthesis of psoralen analogues based on dibenzofuran, Helv. Chim. Acta, 86 (2003) 2900-2907.

[19] A.M.A.G. Oliveira, M.M.M. Raposo, A.M.F. Oliveira-Campos, A.E.H. Machado, P. Puapairoj, M. Pedro, M.S.J. Nascimento, C. Portela, C. Afonso, M. Pinto, Psoralen analogues: synthesis, inhibitory activity of growth of human tumor cell lines and computational studies, Eur. J. Med. Chem., 41 (2006) 367-372.

[20] T. Harayama, K. Nakatsuka, H. Nishioka, K. Murakami, N. Hayashida, H. Ishii, Convenient Synthesis of a Simple Coumarin from Salicylaldehyde and Wittig Reagent .2. Synthesis of Bromocoumarin and Methoxycarbonylcoumarin, Chem. Pharm. Bull., 42 (1994) 2170-2173.

[21] F.P. Guengerich, Special Issue: P450 Catalysis Mechanisms Introduction, Arch. Biochem. Biophys., 507 (2011) 1-2.

[22] S.-F. Zhou, J.-P. Liu, B. Chowbay, Polymorphism of human cytochrome P450 enzymes and its clinical impact, Drug. Metab. Rev., 41 (2009) 89-295.

[23] D.C. Lamb, M.R. Waterman, S.L. Kelly, F.P. Guengerich, Cytochrornes P450 and drug discovery, Curr. Opin. Biotech., 18 (2007) 504-512.

[24] M.L. Panno, F. Giordanno, M.G. Palma, V. Bartella, V. Rago, M. Maggiolini, D. Sisci, M. Lanzino, F. Amicis, S. Ando, Evidence that bergapten, independently of its photoactivation, enhances p53 gene expression and induces apoptosis in human breast cancer cells, Curr. Cancer Drug Targ., 9 (2009) 469-481.

[25] T. Fujioka, K. Furumi, H. Fujii, H. Okabe, K. Mihashi, Y. Nakano, M. Matsunaga, M. Mori, Antiptoliferative constituents from Umbelliferae plants V, A new furanocoumarin and falcarindiol furanocoumarin ethers from root of Angelica japonica, Chem. Pharm. Bull., 47 (1999) 96-100.

[26] E. Lambertini, R. Piva, T.H.K. Mahmud, I. Lampronti, N. Bianchi, M. Borgatti, R. Gambari, Effects of extracts from Bangladeshi medicinal plants on in vitro proliferation of human breast cancer cell lines and expression of estrogen receptor a gene, Int. J. Oncol., 24 (2004) 419-423.

[27] S. Kawaii, Y. Tomono, K. Ogawa, M. Sugiura, M. Yano, Y. Yoshizawa, The antiproliferative effect of coumarins on several cancer cell lines, Anticancer Res. 21 (2001) 917-923.

[28] O.M. Abdel Hafez, K.M. Amin, N.A. Abdel-Latif, T.K. Mohamed, E.Y. Ahmed, T. Maher, Synthesis and antitumor activity of some new xanthotoxin derivatives, Eur. J. Med. Chem. 44 (2009) 2967-2974.

[29] A. Gawron, K. Glowniak, Cystostatic activity of coumarins in vivo, Planta Med., 53 (1987) 526-529.

[30] N. Chaya, K. Terauchi, Y. Yamagata, J. Kinjo, H. Okabe, Antiproliferative constituents in plants. Coumarins and acridone alkaloids from Boenninghausenia japonica Nakai, Biol. Pharm. Bull. 27 (2004) 1312-1316. 
[31] W.N. Setzer, M.C. Setzer, J.M. Schmidt, D.M. Moriarity, B. Vogler, S. Reeb, A.M. Holmes, W.A. Haber, Cytotoxic components from the bark of Stauranthus perforatus from Monteverde, Costa Rica, Planta Med., 66 (2000) 493-494.

[32] X.W. Yang, B. Xu, F.X. Ran, R.G. Wang, J. Wu, J.R. Cui, Inhibitory effects of 11 coumarin compounds against growth of human bladder carcinoma cell line E-J in vitro, J. Chin. Inter. Med., (2007) 1.

[33] D. Kim, Z. Wu, F. Guengerich, Analysis of coumarin 7-hydroxylation activity of cytochrome P450 2A6 using random mutagenesis, J. Biol. Chem., 280 (2005) 40319-40327.

[34] J. Yano, M. Hsu, K. Griffin, C. Stout, E. Johnson, Structures of human microsomal cytochrome P450 2A6 complexed with coumarin and methoxsalen, Nat. Struct. Mol. Biol., 12 (2005) 822-823.

[35] G.M. Morris, R. Huey, W. Lindstrom, M.F. Sanner, R.K. Belew, D.S. Goodsell, A.J. Olson, AutoDock4 and AutoDockTools4: Automated Docking with Selective Receptor Flexibility, J. Comput. Chem., 30 (2009) 2785-2791.

[36] N.S. Cerqueira, J. Ribeiro, P.A. Fernandes, M.J. Ramos, vsLab-An Implementation for Virtual High-Throughput Screening Using AutoDock and VMD, Int. J. Quantum Chem., 111 (2011) 1208-1212.

[37] M.J. Frisch, G.W. Trucks, H.B. Schlegel, G.E. Scuseria, M.A. Robb, J.R. Cheeseman, G. Scalmani, V. Barone, B. Mennucci, G.A. Petersson, H. Nakatsuji, M. Caricato, X. Li, H.P. Hratchian, A.F. Izmaylov, J. Bloino, G. Zheng, J.L. Sonnenberg, M. Hada, M. Ehara, K. Toyota, R. Fukuda, J. Hasegawa, M. Ishida, T. Nakajima, Y. Honda, O. Kitao, H. Nakai, T. Vreven, J. Montgomery, J. A., J.E. Peralta, F. Ogliaro, M. Bearpark, J.J. Heyd, E. Brothers, K.N. Kudin, V.N. Staroverov, R. Kobayashi, J. Normand, K. Raghavachari, A. Rendell, J.C. Burant, S.S. Iyengar, J. Tomasi, M. Cossi, N. Rega, N.J. Millam, M. Klene, J.E. Knox, J.B. Cross, V. Bakken, C. Adamo, J. Jaramillo, R. Gomperts, R.E. Stratmann, O. Yazyev, A.J. Austin, R. Cammi, C. Pomelli, J.W. Ochterski, R.L. Martin, K. Morokuma, V.G. Zakrzewski, G.A. Voth, P. Salvador, J.J. Dannenberg, S. Dapprich, A.D. Daniels, Ö. Farkas, J.B. Foresman, J.V. Ortiz, J. Cioslowski, D.J. Fox, Gaussian, Inc., in, Wallingford CT, 2009. 